\title{
Electrospun Fibre Webs Templated Synthesis of Mineral Scaffolds Based on Calcium Phosphates and Barium Titanate
}

\author{
Cristina Busuioc ${ }^{1}{ }^{(}$, Elena Olaret $^{2}{ }^{\circledR}$, Izabela-Cristina Stancu ${ }^{2}$, Adrian-Ionut Nicoara ${ }^{1}(\mathbb{D}$ and \\ Sorin-Ion Jinga ${ }^{1, *}$ \\ 1 Science and Engineering of Oxide Materials and Nanomaterials Department, University Politehnica of \\ Bucharest, 1-7 Polizu Street, District 1, RO-011061 Bucharest, Romania; cristina.busuioc@upb.ro (C.B.); \\ adi.nicoara18@gmail.com (A.-I.N.) \\ 2 Advanced Polymer Materials Group, Faculty of Applied Chemistry and Materials Science, \\ University Politehnica of Bucharest, 1-7 Polizu Street, District 1, RO-011061 Bucharest, Romania; \\ olaretelena@gmail.com (E.O.); izabela.cristina.stancu@gmail.com (I.-C.S.) \\ * Correspondence: sorinionjinga@yahoo.com; Tel.: +40-21-402-3929
}

Received: 30 March 2020; Accepted: 14 April 2020; Published: 16 April 2020

\begin{abstract}
The current work focuses on the development of mineral scaffolds with complex composition and controlled morphology by using a polymeric template in the form of nonwoven fibre webs fabricated through electrospinning. By a cross-linking process, gelatine fibres stable in aqueous solutions were achieved, these being further subjected to a loading step with two types of mineral phases: calcium phosphates deposited by chemical reaction and barium titanate nanoparticles as decoration on the previously achieved structures. Thus, hybrid materials were obtained and subsequently processed in terms of freeze-drying and heat treating with the purpose of burning the template and consolidating the mineral part as potential bone implants with improved biological response by external stimulation. The results confirmed the tunable morphology, as well as the considerable applicability of both as-prepared and final samples for the development of medical devices, which encourages the continuation of research in the direction of assessing the synergistic contribution of barium titanate domains polarisation/magnetisation by external applied fields.
\end{abstract}

Keywords: fibre webs; electrospinning; calcium phosphates; barium titanate; mineral scaffolds; bone engineering

\section{Introduction}

The field of tissue engineering has grown considerably in recent years, one of the driving forces for such an evolution being the exploration and exploitation of composite biomaterials, which ensure superior performances compared to the unitary counterparts $[1,2]$. In this way, the inherent disadvantages of some materials with demonstrated potential in the medical devices industry were suppressed by combining them with other phases, which made possible the revealing of derivatives with improved properties [3,4] or multifunctional systems [5,6].

Thus, ceramic and polymeric representatives constitute a real resource pool for designing and developing implants dedicated to hard tissue replacement or reconstruction [7]. Starting from the theoretical premises of composition and microstructure related to the natural bone, namely calcium and phosphorus containing mineral phases and specific sponginess that ensure both light weight and adequate mechanical strength [8], a wide range of associations between different types of calcium phosphates and polymers have been proposed [9-11]. Usually, the spongy appearance is artificially generated through the use of porogenous agents [12,13], dedicated techniques [14,15], or sacrificial 
templates [16-18]; further, the size, shape, distribution, and interconnection of the voids must be engineered so as to favour the natural processes from the implant-living tissue interface [19]. Another territory with huge potential is represented by the development of smart biomaterials, which allow an external stimulation of the physiological microenvironment, offering beneficial conditions for the cellular metabolism. In this respect, different materials with electrical or magnetic properties have been integrated into older efficient systems or processed as novel devices for the field of hard tissue engineering [20-22].

Among the broad variety of techniques dedicated to the production of porous three-dimensional structures, electrospinning is the most approached due to its simplicity, but also because it generates materials with a large surface-to-volume ratio and suitable microstructure for bone implants $[23,24]$. Even though most of the products are of organic nature $[25,26]$, there are also examples of electrospun ceramic webs [27]. Moreover, biopolymers have become extremely attractive lately due to their biocompatibility, biodegradability, and low cost, which are features that led to various medical applications, such as encapsulation and the release of bioactive molecules, reinforcing agents for different matrices, or diagnostic and therapeutic imaging [28,29]. In this context, gelatine is a protein of natural origin that is obtained by collagen hydrolysis; briefly, it is a biopolymer that meets all the requirements imposed in the field of tissue engineering [30-32]. On another hand, calcium phosphates are of great interest due to their biocompatibility and bioactivity [33-35], the most known representatives being hydroxyapatite $\left(\mathrm{Ca}_{10}\left(\mathrm{PO}_{4}\right)_{6}(\mathrm{OH})_{2}\right)$, dicalcium phosphate dihydrate $\left(\mathrm{CaHPO}_{4} \cdot 2 \mathrm{H}_{2} \mathrm{O}\right)$, octacalcium phosphate $\left(\mathrm{Ca}_{8} \mathrm{H}_{2}\left(\mathrm{PO}_{4}\right)_{6} \cdot 5 \mathrm{H}_{2} \mathrm{O}\right)$, dicalcium phosphate $\left(\mathrm{CaHPO}_{4}\right)$, tricalcium phosphate $\left(\mathrm{Ca}_{3}\left(\mathrm{PO}_{4}\right)_{2}\right)$, tetracalcium phosphate $\left(\mathrm{Ca}_{4} \mathrm{O}\left(\mathrm{PO}_{4}\right)_{2}\right)$, and calcium pyrophosphate $\left(\mathrm{Ca}_{2} \mathrm{P}_{2} \mathrm{O}_{7}\right)$ [36]. Thus, the fabrication of composite fibres seems to be a solution for many ongoing medical issues [37]. K. Chan et al. [38] studied the combination of polylactic acid with different oxide ceramics, since such electrospun composite scaffolds can provide osteogenic properties, while D. Santos et al. [39] demonstrated that an electrospun membrane of polylactic acid with glass-reinforced hydroxyapatite microparticles represents an environment that enhances cell proliferation. M.K. Ahmed et al. [40] reported the fabrication through the electrospinning of composite scaffolds based on polycaprolactone microfibers with alumina and selenite-doped carbonated hydroxyapatite content, showing that a variable ratio between the two ceramic additives allows properties' tuning. In order to surpass the infections complication in orthopaedic surgery, Liu et al. [41] proposed a complex system based on polylactic acid fibres, hydroxyapatite nanowires, polydopamine adhesive, silver nanoparticles, and a polypyrrole mediator. Other approaches consist of coating the electrospun polymeric fibre webs with metallic [42] or ceramic [43] layers to increase the hydrophilicity, biocompatibility, or bioactivity, as well as employing the electrospun membrane as a template [44] to retain the primary microstructure.

Moving to the possibility of local stimulation at the affected area, this can be achieved by using piezoelectric, ferroelectric, or ferromagnetic materials that are distributed in a controlled manner and activated by the application of external electric or magnetic fields, subsequently improving the speed and quality of tissue regeneration by modifying the biological routes travelled by the cells [45]. One such example is barium titanate $\left(\mathrm{BaTiO}_{3}\right)$, which is a well-known ceramic with unique properties $[16,46-49]$. It was demonstrated that the integration of hydroxyapatite and barium titanate powders in a collagen matrix can improve the osseointegration process of the resulting hybrid scaffolds [47], the influence of barium titanate being afterwards evaluated through numerical simulation [46]. Composite scaffolds based on calcium phosphates and barium titanate were also manufactured by bacterial cellulose templated synthesis, being well accepted by the mesenchymal stem cell cultures [16].

In conclusion, the microstructure of a bone substitute must meet the requirements related to the macropores' proportion and their mode of assembly so as to allow a facile penetration of cells and ensure the local integrity when subjected to medium and heavy loads. As a result, the present work proposes a new route for obtaining porous three-dimensional structures based on calcium phosphates and barium titanate, this being the first attempt of this kind in the field. The current technological flow is based on the use of an electrospun fibre web as a template and porogenous agent simultaneously, 
which is loaded/decorated with mineral phases by chemical synthesis in solution or physical attachment from suspension and subsequently removed from the system by heat treatment.

\section{Materials and Methods}

\subsection{Fibrous Template Production}

Firstly, a fibrous fish gelatine $(\mathrm{Gel})$ web was fabricated through the electrospinning technique (Electrospinning Apparatus EC-CLI, IME Technologies). Basically, a 70\% w/v fish Gel precursor solution was prepared by dissolving the corresponding amount of protein in double-distilled water under continuous stirring in a water bath at $40^{\circ} \mathrm{C}$ for at least $4 \mathrm{~h}$. The obtained solution was loaded in a 5-mL syringe after reaching room temperature $\left(25^{\circ} \mathrm{C}\right)$ and subjected to the electrospinning process, according to the following parameters: $7 \mu \mathrm{L} / \mathrm{min}$ feeding rate, $21 \mathrm{kV}$ applied voltage, $5 \mathrm{~mm} / \mathrm{s}$ needle moving speed, and a $70 \mathrm{rpm}$ collector $(2 \mathrm{~cm}$ diameter) rotating speed, respectively. The equipment is provided with an environmental control cabinet, which kept the temperature $\left(25^{\circ} \mathrm{C}\right)$ and relative humidity $(40 \%)$ constant during the entire fabrication process. Secondly, the detached $\mathrm{Gel}$ fibre web was stabilised against aqueous media by a cross-linking process. In this respect, the fibrous substrate was incubated in a $0.5 \%$ glutaraldehyde ethanolic solution for 4 days at $25^{\circ} \mathrm{C}$ and washed for additional 5 days, as follows: 3 days rinsing with ethanol and 2 days rinsing with double-distilled water. The obtained fibre template was kept at $4{ }^{\circ} \mathrm{C}$ before further use.

Such fibrous substrates can be integrated in a wide range of medical applications, as previously reported: selective separation, the immobilisation of active agents, wound healing, artificial skin, drug delivery, scaffold for tissue engineering, nervous system, and bone tissue engineering [50].

\subsection{Hybrid Composites Synthesis}

In the second step, the template with a fibrous three-dimensional structure was loaded with calcium phosphates (CPs), resulting in a hybrid composite consisting of a network of randomly distributed polymeric fibres covered with a layer of CPs having different compositions, which are most likely a combination between brushite $\left(\mathrm{CaHPO}_{4} \cdot 2 \mathrm{H}_{2} \mathrm{O}\right)$ as a major phase and hydroxyapatite $\left(\mathrm{Ca}_{10}\left(\mathrm{PO}_{4}\right)_{6}(\mathrm{OH})_{2}\right)$ as a minor phase [51]. A deposition cycle involved the mineral phases loading onto the template, which was cut into pieces of $1.5 \times 1.5 \mathrm{~cm}^{2}$ by a chemical reaction in liquid medium. First, the electrospun fibre webs were immersed in $100 \mathrm{~mL} 0.5 \mathrm{M}$ calcium nitrate tetrahydrate $\left(\mathrm{Ca}\left(\mathrm{NO}_{3}\right)_{2} \cdot 4 \mathrm{H}_{2} \mathrm{O}\right.$, Merck) aqueous solution, with $\mathrm{pH}$ adjusted to $10-11$ with an ammonium hydroxide $\left(\mathrm{NH}_{4} \mathrm{OH}\right)$ aqueous solution and maintained under ultrasonication for $15 \mathrm{~min}$. Then, they were removed and immersed in $100 \mathrm{~mL} 0.5 \mathrm{M}$ ammonium phosphate dibasic $\left(\left(\mathrm{NH}_{4}\right)_{2} \mathrm{HPO}_{4}\right.$, Merck) aqueous solution for another $15 \mathrm{~min}$ under ultrasonication. This two-step synthesis represents a deposition cycle; for several cycles, the immersion procedures in the solutions containing $\mathrm{Ca}^{2+}$ and $\mathrm{PO}_{4}{ }^{3-}$ were repeated in the same order. The samples were coded Gel-CPs-1c in the case of applying one deposition cycle and Gel-CPs-3c for three such cycles.

The third step involved the decoration of the hybrid composite obtained in the previous stage with barium titanate (BT) nanoparticles synthesised by combining the sol-gel method with a hydrothermal treatment [48]. Thus, the dried gel, formed following the hydrolysis and polycondensation processes, was autoclaved at $120^{\circ} \mathrm{C}$ for $24 \mathrm{~h}$, filtered, and dried, resulting in a white powder. This was added to $\left(\mathrm{NH}_{4}\right)_{2} \mathrm{HPO}_{4}$ solution in the amount of $0.5 \mathrm{~g}$, and the same protocol was followed with the aim of ensuring both loading with CPs and decoration with BT nanoparticles. The attained sample is further referred as Gel-CPs-BT-3c, taking into account the fact that BT was associated only with the three cycles derived composites, since usually a larger amount of material is needed to ensure the formation of a self-sustained structure.

The as-prepared samples were freeze-dried (freeze-drying process under standard conditions) to preserve the porous three-dimensional structure of the template and obtain spongy composite materials. The advantages of the present route consist of the high purity and homogeneity of CPs 
deposition due to the ionic contact between reactants in liquid medium; the tetragonal crystalline symmetry of BT nanoparticles due to the applied hydrothermal treatment, which could provide a measurable response to external stimuli, so that the physiological microenvironment could become more attractive to the cells; and nanoscale mixing of the constituent phases due to the application of ultrasounds to facilitate the penetration of the precursor solutions/suspension in the volume of the electrospun fibre web.

\subsection{Mineral Scaffolds Fabrication}

In the last step, the composites described above (Gel fibre webs-CPs layer-BT nanoparticles) were heat treated in air, under different experimental conditions, in order to remove the polymeric template by combustion, complete the crystallisation of CPs, and generate mineral scaffolds with various morphologies. Simultaneously, the achievement of a mechanical resistance suitable for bone substitute applications was targeted. More exactly, the selected values of the heat treatment parameters for obtaining porous three-dimensional structures were a heating rate of $60^{\circ} \mathrm{C} / \mathrm{h}$ up to $300{ }^{\circ} \mathrm{C}, 120{ }^{\circ} \mathrm{C} / \mathrm{h}$ up to $600{ }^{\circ} \mathrm{C}$, and $600{ }^{\circ} \mathrm{C} / \mathrm{h}$ up to the maximum temperature, $800{ }^{\circ} \mathrm{C}, 1000{ }^{\circ} \mathrm{C}$, or $1200{ }^{\circ} \mathrm{C}$ maximum temperature, and a $2 \mathrm{~h}$ period at maximum temperature (Figure 1). A reference is made to the obtained samples by mentioning the temperature at which they were processed $\left(800^{\circ} \mathrm{C}, 100{ }^{\circ} \mathrm{C}\right.$, and $\left.1200{ }^{\circ} \mathrm{C}\right)$.

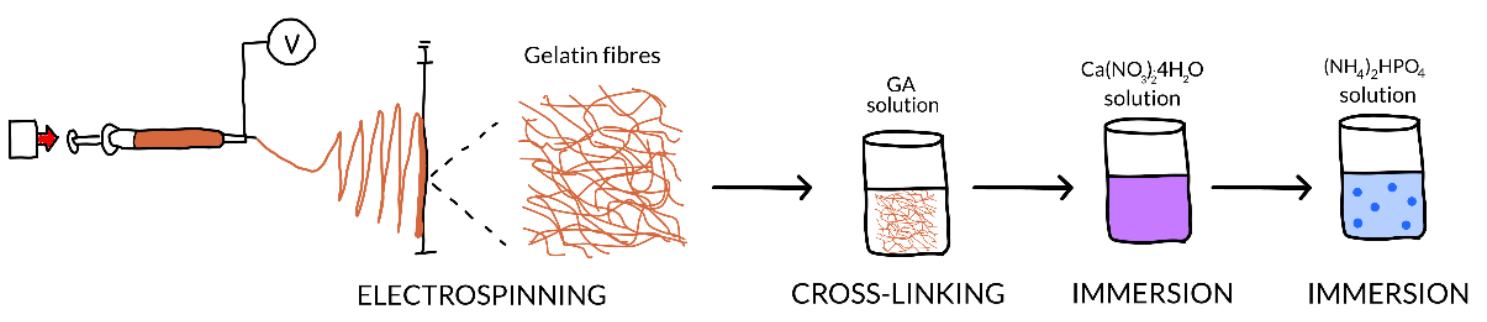

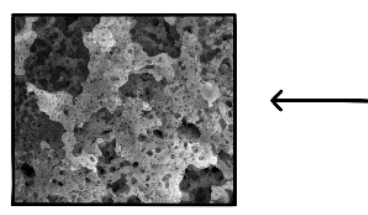

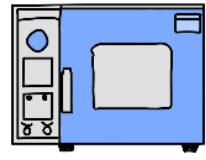

HEAT TREATMENT

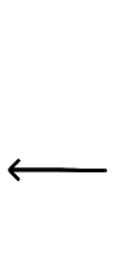

FREEZE-DRYING
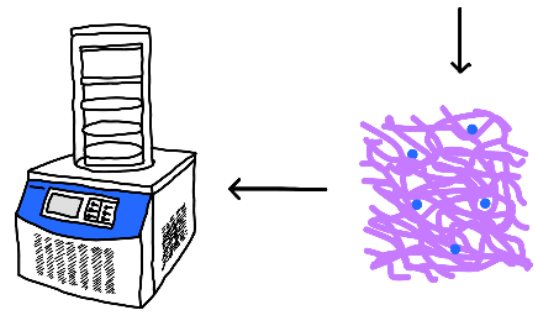

EXTRACTION

Figure 1. Schematic representation of the technological flow.

The current approach is characterised by its use of cheap and widely available materials, as well as simple and accessible techniques, while the structural, morphological, and biological properties of the final materials can be adapted to the clinical particularities of each patient, with a significant reduction of the healing period and improvement of the life quality during recovery.

\subsection{Materials Characterisation}

The samples were characterised from the material point of view: thermal, compositional, structural, and morphological. The thermal analysis was conducted from room temperature to $1000{ }^{\circ} \mathrm{C}, 5^{\circ} \mathrm{C} / \mathrm{min}$ temperature rate, in air, on a Shimadzu DTG-60 equipment (Shimadzu Corporation, Kyoto, Japan). The mineralogical composition and crystalline structure were evaluated by X-ray diffraction (XRD), with a Shimadzu XRD 6000 diffractometer (Shimadzu Corporation, Kyoto, Japan) with Ni-filtered Cu $K \alpha$ radiation $\left(\lambda=1.54 \AA\right.$ ) , $2 \theta$ ranging between 10 and $80^{\circ}$, a $0.02^{\circ}$ step size, a $2^{\circ} / \mathrm{min}$ scan speed, and $0.6 \mathrm{~s}$ preset time. The vibrational features were analysed by Fourier transform infrared (FTIR) spectroscopy, with a Thermo Scientific Nicolet iS50 spectrophotometer (Thermo Fisher Scientific, Waltham, MA, 
USA), using the attenuated total reflection (ATR) module, the wavenumber ranging between 400 and $4000 \mathrm{~cm}^{-1}$, 32 scans per sample, and $4 \mathrm{~cm}^{-1}$ resolution, as well as by Raman spectroscopy, with a Horiba Confocal LabRAM HR Evolution spectrophotometer (Horiba, Kyoto, Japan), using a 633 nm laser, $100 \%$ ND filter, $50 \times$ objective, and $600 \mathrm{gr} / \mathrm{mm}$ grating, the wavenumber ranging between 200 and $1000 \mathrm{~cm}^{-1}, 10$ scans per sample, and $10 \mathrm{~s}$ per scan. The morphology was revealed by scanning electron microscopy (SEM), with a Thermo Scientific Verios G4 (Thermo Fisher Scientific, Waltham, MA, USA) (for barium titanate powder; $2 \mathrm{kV}$ accelerating voltage, $2 \mathrm{~mm}$ working distance and no metallic coating) or Quanta Inspect F microscope (FEI Company, Hillsboro, OR, USA) equipped with an energy-dispersive X-ray spectroscopy (EDX) probe (for all the other samples; $30 \mathrm{kV}$ accelerating voltage, $10 \mathrm{~mm}$ working distance, and gold coating by DC magnetron sputtering for $60 \mathrm{~s}$ ).

\section{Results and Discussion}

The bear and loaded fibre webs were characterised regarding their thermal behaviour when heated from room temperature up to $1000{ }^{\circ} \mathrm{C}$ (Figure 2). As it was expected, the Gel sample is completely burnt at the final temperature, with $100 \%$ weight loss, this being divided in several steps, with the major one occurring at approximately $320^{\circ} \mathrm{C}$ (protein thermal degradation or decomposition); this value is a little bigger than those previously reported $\left(250-300^{\circ} \mathrm{C}\right)$ [52], which is an aspect that can be correlated with the cross-linking procedure and higher degree of crystallinity that the electrospun fibre web displays (Figure 4a). The shape of the weight loss curves (Figure 2a) changes when it comes to the composite samples, with a significant difference in the final weight loss between the one and three cycles of derived materials: 56\% for Gel-CPs-1c and 45\% for Gel-CPs-3c and Gel-CPs-BT-3. These values indicate at least two findings: the application of multiple deposition cycles is not a linear process of increasing the loading quantity and the developed protocol generates reproducible samples, since the value is identical for the two specimens obtained after applying three deposition cycles (the amount of BT decoration is reduced and does not modify the overall trend). Moreover, in these three last cases, the major weight loss shifts to $210^{\circ} \mathrm{C}$, which is related to the loss of adsorbed, absorbed, and bounded water, while the core fibres seem to be somehow protected by the mineral shell, pushing the degradation processes to higher temperatures. Thus, depending on the number of applied deposition cycles, the degree of loading with mineral phases can be controlled so that the fibre coating layer reaches the desired thickness (Figure $5 b, c$ ). The proposed phenomena are also sustained by the thermal effects shown in Figure 2b: a succession of endothermic processes at small temperatures, followed by several exothermic processes above $220^{\circ} \mathrm{C}$.

Before integrating the BT phase within the composite system, it was investigated separately in order to reveal its crystallinity and morphology. Figure 3a presents the corresponding XRD pattern, which indicates the obtaining of the perovskite structure with cubic symmetry (ICDD 04-007-6869). However, the powder was also studied by Raman spectroscopy in order to identify possible differences in symmetry compared to the former diffractogram, because the dried gel was autoclaved and, in this way, it was subjected to high pressure. The resulting Raman spectrum (Figure $3 b$ ) contains four vibrational bands, from which the one at $305 \mathrm{~cm}^{-1}$ is the most important, since it is correlated with the existence of a tetragonal symmetry [47,53,54]. This apparent contradiction can be explained based on the distortion of the cubic structure into a pseudo-cubic or slightly tetragonal one. Such an assertion, together with the emergence of oxygen vacancies at the particles surface, trigger peculiar magnetic properties, namely an unexpected ferromagnetism at room temperature; thus, $\mathrm{Ti}^{3+}$ or $\mathrm{Ti}^{2+}$ ions appear, offering a non-zero magnetisation below a critical nanoparticle size, as well as a multiferroic behaviour $[48,55,56]$. This phenomenon can be subsequently exploited in the direction of local stimulation of the cell physiological microenvironment. Figure 3c exhibits an SEM image of the same powder, emphasising individual spherical particles with dimensions below $10 \mathrm{~nm}$ but gathered as rounded aggregates of few hundreds of nm. 

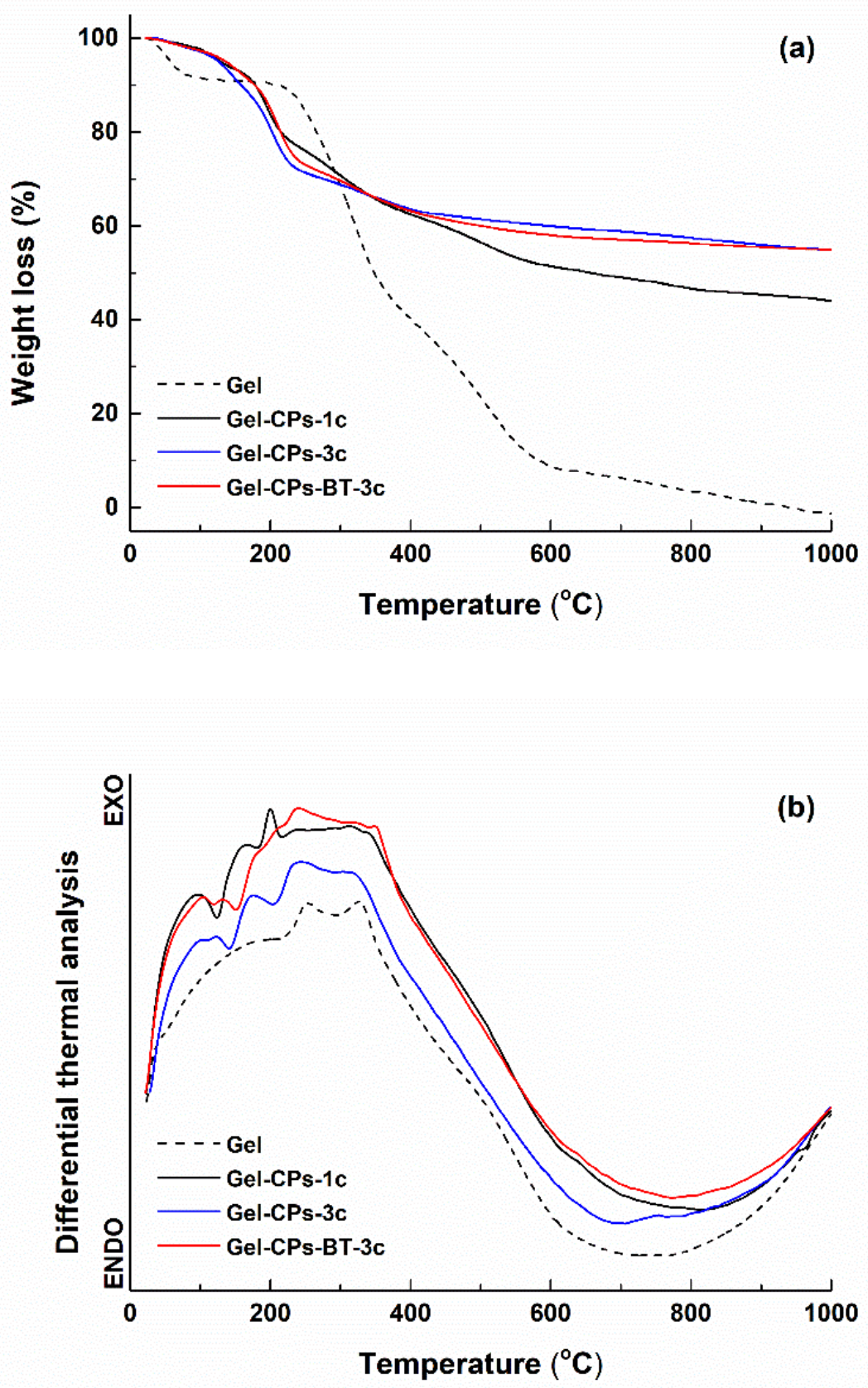

Figure 2. Complex thermal analyses of the template and as-prepared composites: (a) weight loss and (b) differential thermal analysis.

The XRD patterns of the as-prepared and heat-treated samples can be visualised in Figure 4. In the case of the Gel fibre web, a quite increase crystallinity is confirmed through the intense and narrow diffraction maxima. The fibrous template subjected to a three-cycle deposition is covered with a mixture of dicalcium phosphate dihydrate $\left(\mathrm{CaHPO}_{4} \cdot 2 \mathrm{H}_{2} \mathrm{O}\right)$, which is commercially called brushite, with a monoclinic structure (ICDD 00-072-0713) and calcium phosphate hydroxide $\left(\mathrm{Ca}_{10}\left(\mathrm{PO}_{4}\right)_{6}(\mathrm{OH})_{2}\right)$, known as hydroxyapatite, with hexagonal symmetry (ICDD 00-072-1243); the first phase is a majority, while the second one is a minority (Figure 4a). The addition of BT nanoparticles to the precursor solution changes to a certain extent the thermodynamics of the chemical reactions, since the ratio between the two mentioned CPs is reversed such that hydroxyapatite becomes quantitatively predominant; this can be attributed to a slight modification of $\mathrm{pH}$, with significant repercussions on the entire process. 

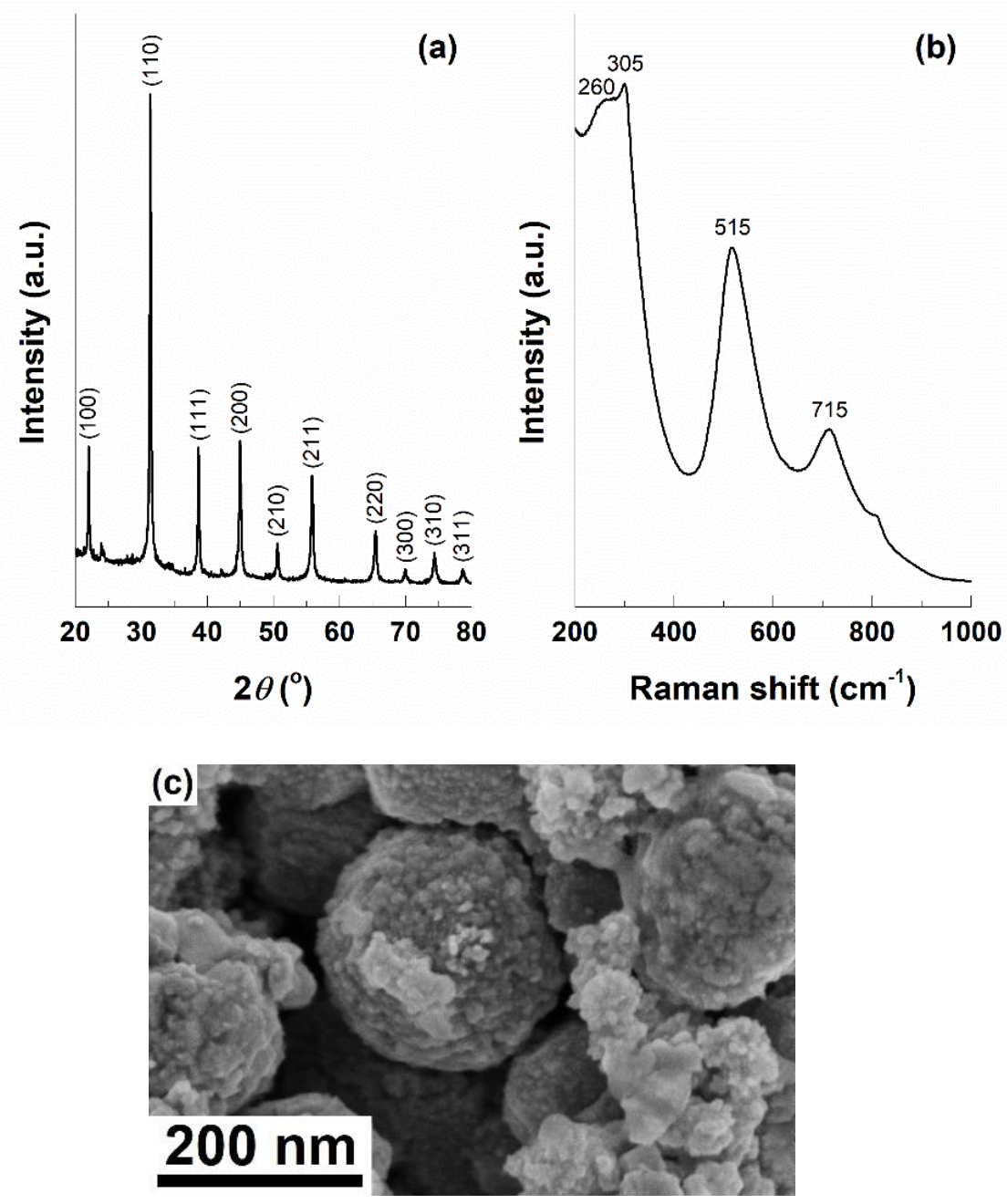

Figure 3. (a) XRD pattern, (b) Raman spectrum and (c) SEM image of barium titanate (BT) powder.

Going to the mineral composites achieved after the thermal treatments (Figure $4 \mathrm{~b}$ ), the temperatures of 800 and $1000{ }^{\circ} \mathrm{C}$ lead to tetragonal (ICDD 00-009-0346) calcium pyrophosphate $\left(\mathrm{Ca}_{2} \mathrm{P}_{2} \mathrm{O}_{7}\right)$, while its growth to $1200{ }^{\circ} \mathrm{C}$ generates a combination of major orthorhombic (ICDD 00-009-0345) calcium pyrophosphate, and minor monoclinic (ICDD 00-029-0359) tricalcium phosphate $\left(\mathrm{Ca}_{3}\left(\mathrm{PO}_{4}\right)_{2}\right)$, which is in good agreement with our previous work [17]. The BT amount is again too small to be detected by the X-ray diffractometer.

It has already been reported that calcium pyrophosphate represents a promising candidate in the field of tissue engineering. Thus, the influence of doping on calcium pyrophosphate phase transformation, bulk densification, as well as cell proliferation was studied, showing a great potential for use in biomedical applications [57]. Calcium pyrophosphate powder was also integrated in chitosan or chitosan-gelatine matrices, which enhanced the mechanical properties and accelerated the mineralisation process, the derived systems being suitable for bone substitutes [58]. Calcium pyrophosphate was likewise composited with Ti-13Nb-13Zr alloy, demonstrating excellent mechanical and corrosion properties, high biocompatibility and bioactivity and, at the end, potential for orthopaedic implants [59]. Not least, the resorption simulation showed that the rate in the case of calcium pyrophosphate is lower than that for tricalcium phosphate and hydroxyapatite, which was associated with a weaker protonation of $\left(\mathrm{P}_{2} \mathrm{O}_{7}\right)^{4-}$ ions during ceramic dissolution [60]. 

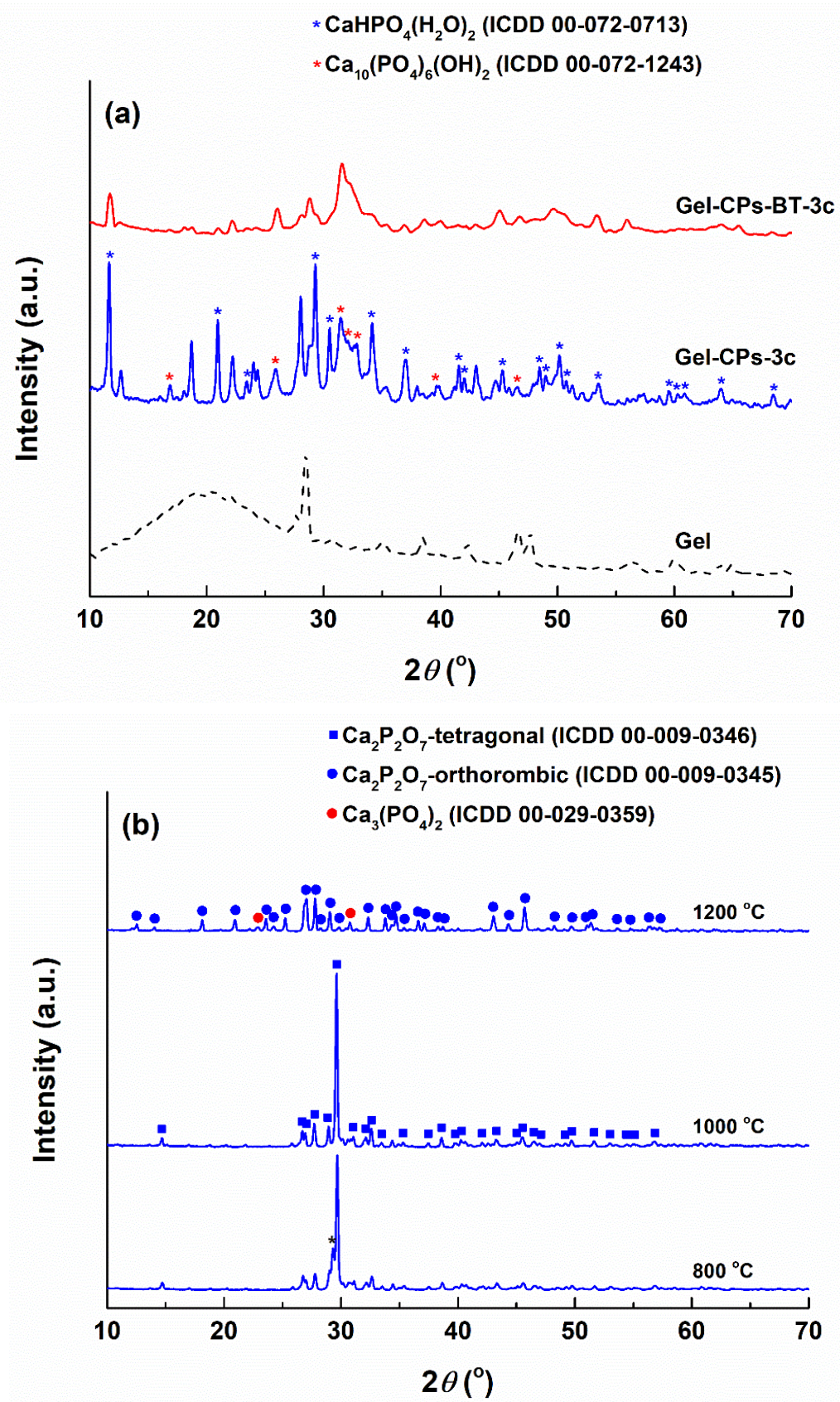

Figure 4. XRD patterns of the obtained materials: (a) before the thermal treatments and (b) after the thermal treatments of the Gel-CPs-3c composite.

The microstructure of the as-prepared and heat-treated scaffolds is evidenced in the SEM images centralised in Figures 5 and 6. The bear Gel web is made of continuous nonwoven fibres, which are homogenous in thickness and randomly distributed in several tens of overlapping layers; their diameter falls within the range of 600-700 nm (Figure 5a,a'). After the loading process, the fibres get covered with CPs nanosheets packed in a loose way and radially arranged in relation to the main axis of the cylindrically shaped substrate. The final thickness of the whole structure is of $2-3 \mu \mathrm{m}$ for Gel-CPs-1c (Figure 5b,b') and 4-5 $\mu \mathrm{m}$ for Gel-CPs-3c (Figure 5c, $\mathrm{c}^{\prime}$ ), which means a mineral layer varying between $700 \mathrm{~nm}$ and $2.2 \mu \mathrm{m}$. When it comes to BT decoration, Figure $5 \mathrm{~d}, \mathrm{~d}^{\prime}$, meaning SEM images based on the detected backscattered electrons, confirm its presence through the brighter domains, as well as physical attachment as aggregates of different sizes and shapes. 


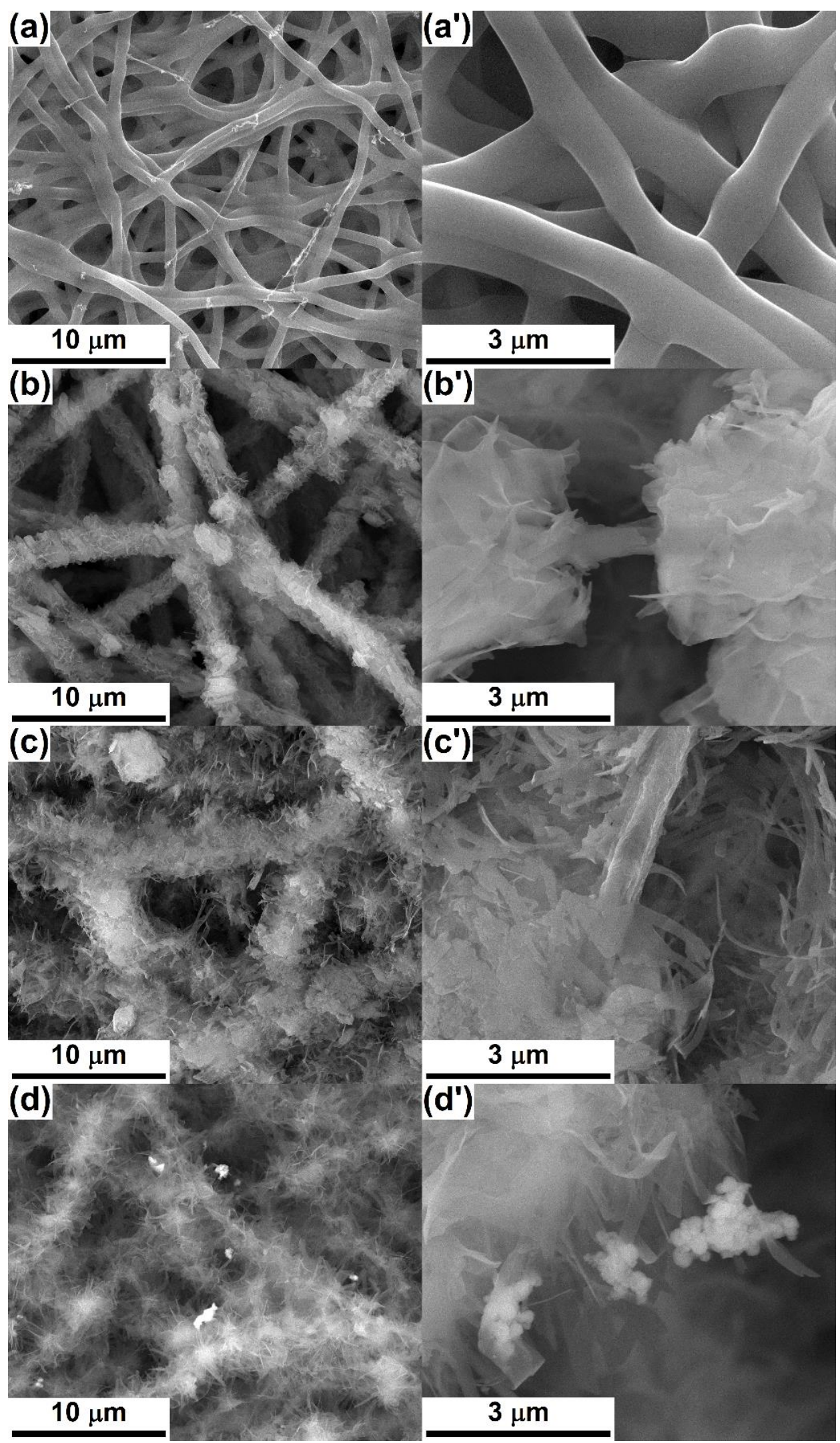

Figure 5. SEM images of: (a, $\left.\mathbf{a}^{\prime}\right)$ Gel fibre web, $\left(\mathbf{b}, \mathbf{b}^{\prime}\right)$ Gel-CPs-1c composite, (c, $\left.\mathbf{c}^{\prime}\right)$ Gel-CPs-3c composite and (d,d') Gel-CPs-BT-3c. 
Figure 6 gives some examples of morphologies resulted for three deposition cycles and different temperature values. All the entities are three-dimensional and porous, showing the influence of the heat treatment on the grains dimension, shape, and interconnection, as well as pores ratio, size, geometry, and distribution within the volume. The samples thermally treated at $800{ }^{\circ} \mathrm{C}$ consist of elongated grains, even acicular sometimes, copying the spatial arrangement of the primary Gel fibres, but reduced in diameter (below $300 \mathrm{~nm}$ ) due to polymer combustion and mineral phases shrinkage; such certain structures join in porous walls or bodies, which could contribute to the achievement of an appropriate mechanical resistance (Figure 6a,a'). As well, large pores, with sizes up to $4 \mu \mathrm{m}$ and united in the form of a channel system that crosses the entire volume of the scaffold and seems suitable for the localisation of cells, are clearly visible. Going further to $1000^{\circ} \mathrm{C}$, it is obvious that the grains become larger (up to $2 \mu \mathrm{m})$, more rounded, and interconnected as a three-dimensional skeleton that is superposed over a network of branched pores; occasionally, between the main sustaining elements of this architecture, thin and soft filling panels occur, especially when BT is not involved, such a reinforcement being more prone to sustain device integrity in applications with frequent mechanical loads (Figure $6 b, b^{\prime}$ ). With respect to the pores aspect, the trend can be divided in two directions, depending on the existence of the BT phase; thus, BC-CPs-3c (Figure 6b) exhibits smaller voids (below $2 \mu \mathrm{m}$ ) compared to the lower temperature counterpart (Figure 6a), which appeared due to the material shrinkage and could hinder the cells' movement, while BC-CPs-BT-3c (Figure 6b') preserves the empty areas and even expands them to $10 \mu \mathrm{m}$, as a consequence of material contraction only at the level of grains agglomeration, with the complete elimination of the elongated and parallel pores (Figure 6a'), which could provide a proper environment for the cells' paths. Increasing the temperature to $1200{ }^{\circ} \mathrm{C}$ favours the material diffusion, leading to lower porosity, the appearance of bigger grains, and new bridges between them, which is equivalent to a densified material, with stronger links between components and beneficial effects on the mechanical properties (Figure $6 c, c^{\prime}$ ). The scaffold without BT (Figure $6 c$ ) is the most massive, with interconnected pores having dimensions of maximum $7 \mu \mathrm{m}$ and homogenously distributed within the volume, as a well-established circulation network. Contrariwise, the one with decoration (Figure 6 $c^{\prime}$ ) displays voids with a broad size distribution, different shapes, and variable degrees of binding; this look is the result of a preferential evolution and material displacement, which is in close connection with the local compositional and morphological particularities of the as-prepared sample. Considering the effect of BT nanoparticles decoration, this can be quantified starting from the differences in mineralogical composition both before and after the heat treatments (Figure 4), which are translated into a hindered densification and spongy character. This aspect can potentiate the biological response by at least two ways: on one hand, it offers an extended interface for the cells and, on the other hand, an external stimulation can be carried out by means of electrical/magnetic nature.

In this context, M. Ahmed et al. [61] approached the effect of the physical features of the fibrous scaffolds on cell migration and colonisation, concluding that the fibre diameter influences both cell morphology and alignment. Moreover, the importance of the fibres' orientation for guided bone repair and reconstruction was also approached [62,63]. A comparison with our previously published articles on the same topic, but employing bacterial cellulose as a template, leads to the following statements: the first one addresses a material composed of BT grains interconnected in a branched structure and decorated with small clusters of CPs particles [16], the second describes highly porous three-dimensional architectures consisting of calcium pyrophosphate grains that sometimes bind in micro-sized walls [17], while the third one reports about buchwaldite and a hydroxyapatite-based scaffold made of a mixture of linked grains and rods or with trabecular aspect [18]. All these confirm the possibility of composition and morphology tuning via template selection, precursor combination, loading degree, and thermal parameters. 

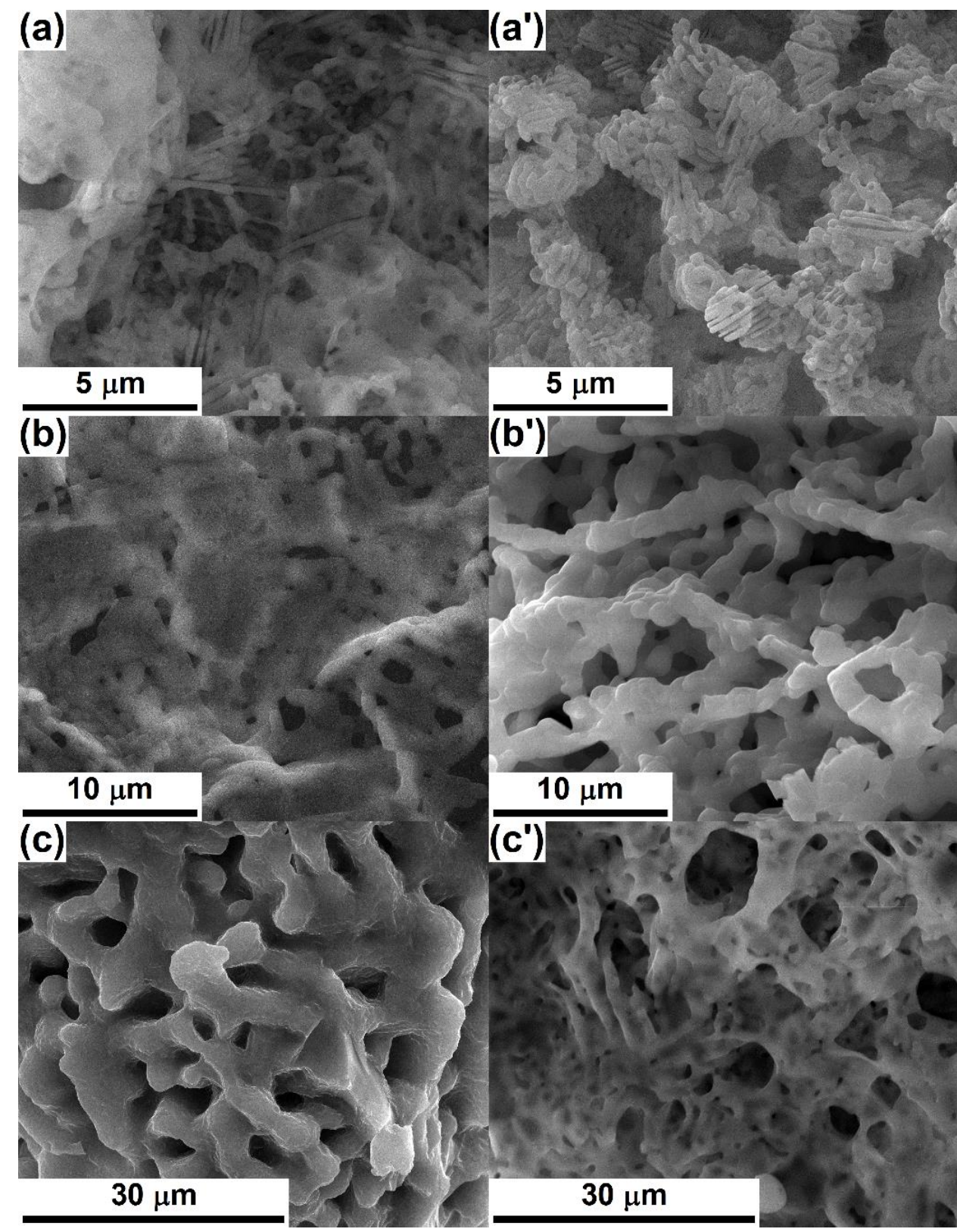

Figure 6. SEM images of Gel-CPs-3c composite thermally treated at: (a) $800{ }^{\circ} \mathrm{C}$, (b) $1000{ }^{\circ} \mathrm{C}$, and (c) $1200{ }^{\circ} \mathrm{C}$ and Gel-CPs-BT-3c composite thermally treated at $\left(\mathbf{a}^{\prime}\right) 800{ }^{\circ} \mathrm{C},\left(\mathbf{b}^{\prime}\right) 1000{ }^{\circ} \mathrm{C}$, and $\left(\mathbf{c}^{\prime}\right) 1200^{\circ} \mathrm{C}$.

The evolution of the elemental composition during the loading/decoration procedures, as well as the situation of the thermally treated samples are highlighted in Figure 7. If $\mathrm{Gel}$ fibres consist of C, $\mathrm{N}$, and $\mathrm{O}$, these signals are shielded by the mineral coating that exceeds $700 \mathrm{~nm}$, resulting in intense maxima for $\mathrm{Ca}$ and $\mathrm{P}$, which is attributed to $\mathrm{CPs}$, and weak peaks for $\mathrm{Ba}$ and $\mathrm{Ti}$, which are assigned to BT (Figure 7a). Indeed, the detection of BT through this investigation method was possible only when recording the generated signals on an area previously validated as containing nanoparticle aggregates; otherwise, it is quite difficult to obtain a detectable contribution of this phase in the EDX spectrum, since the quantitative ratio between $\mathrm{BT}$ and $\mathrm{CPs}$ is extremely reduced even though $0.5 \mathrm{~g}$ of BT powder was added to $\left(\mathrm{NH}_{4}\right)_{2} \mathrm{HPO}_{4}$ solution (only a small part of this amount was physically attached to CPs nanosheets). The other set of EDX spectra (Figure $7 \mathrm{~b}$ ) confirms the evanescence of the polymeric template (residual signals could come from the carbon tape employed for fixing the sample before analysis or adsorbed molecules of nitrogen from the surrounding atmosphere), together 
with the presence of the expected elements $(\mathrm{Ca}, \mathrm{P}, \mathrm{Ba}, \mathrm{Ti}$, and $\mathrm{O})$ belonging to the scaffolds without or with BT nanoparticles decoration. Referring to the associated compositional data extracted from the previously discussed EDX spectra, it is obvious that all the values, as well as the differences from one specimen to another, falls within the detection limits of the EDX probe, confirming the reproducibility of the developed synthesis route.

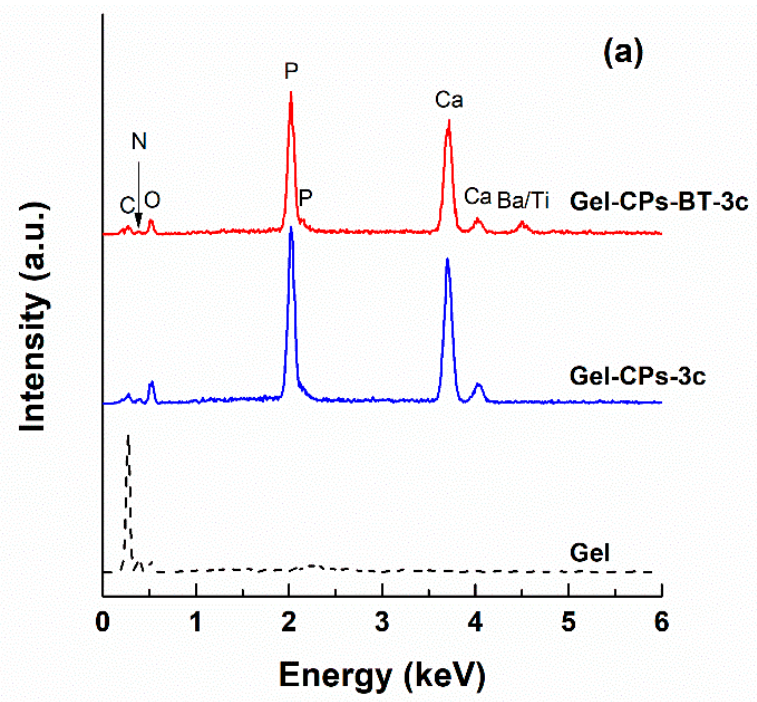

\begin{tabular}{cccccccc}
\hline \multirow{2}{*}{ Sample } & \multicolumn{7}{c}{ Composition (wt \%) } \\
\cline { 2 - 8 } & $\mathbf{C}$ & $\mathbf{N}$ & $\mathbf{O}$ & $\mathbf{C a}$ & $\mathbf{P}$ & $\mathbf{B a}$ & $\mathbf{T i}$ \\
\hline Gel & 51.69 & 35.68 & 12.63 & - & - & - & - \\
\hline Gel-CPs-3c & 5.34 & 10.35 & 23.56 & 36.78 & 23.97 & - & - \\
\hline Gel-CPs-BT-3c & 6.98 & 5.46 & 18.18 & 37.68 & 24.32 & 4.19 & 3.19 \\
\hline
\end{tabular}

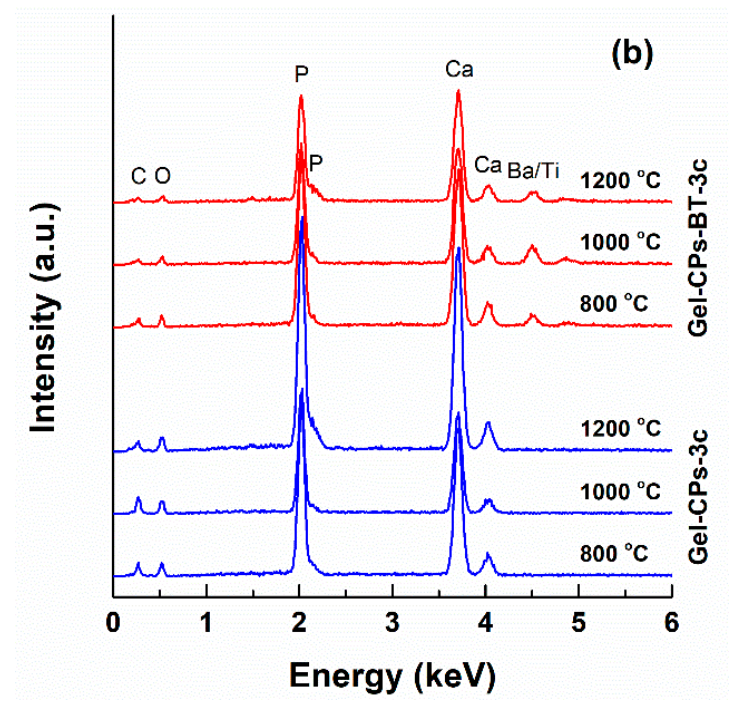

\begin{tabular}{|c|c|c|c|c|c|}
\hline \multirow{2}{*}{ Sample } & \multicolumn{5}{|c|}{ Composition (wt \%) } \\
\hline & $\mathrm{Ca}$ & $\mathbf{P}$ & $\mathrm{O}$ & $\mathbf{B a}$ & Ti \\
\hline Gel-CPs-3c $800^{\circ} \mathrm{C}$ & 40.75 & 32.40 & 26.85 & - & - \\
\hline Gel-CPs-3c $1000^{\circ} \mathrm{C}$ & 35.62 & 28.65 & 35.73 & - & - \\
\hline Gel-CPs-3c $1200^{\circ} \mathrm{C}$ & 41.79 & 31.76 & 26.45 & - & - \\
\hline Gel-CPs-BT-3c $800^{\circ} \mathrm{C}$ & 42.31 & 31.57 & 20.23 & 3.18 & 2.71 \\
\hline Gel-CPs-BT-3c $1000^{\circ} \mathrm{C}$ & 39.34 & 28.32 & 20.02 & 6.78 & 5.54 \\
\hline Gel-CPs-BT-3c $1200^{\circ} \mathrm{C}$ & 41.84 & 28.62 & 21.51 & 4.01 & 4.02 \\
\hline
\end{tabular}

Figure 7. Energy-dispersive X-ray spectroscopy (EDX) spectra and corresponding elemental compositions of the obtained materials: (a) before the thermal treatments and (b) after the thermal treatments. 
The way in which the formerly identified elements are linked in chemical groups can be analysed using the FTIR spectra (Figure 8). The specific absorption bands of Gel template are placed in the amide band region: amide I at $1646 \mathrm{~cm}^{-1}$, amide II at $1538 \mathrm{~cm}^{-1}$, and amide III at $1239 \mathrm{~cm}^{-1}$ [64]. Going to the coated fibres, the corresponding curves contain identification elements for an $\left(\mathrm{HPO}_{4}\right)^{3-}$ group coming from brushite at 1090, 1071, and $970 \mathrm{~cm}^{-1}[65], \mathrm{a}\left(\mathrm{PO}_{4}\right)^{3-}$ group belonging to hydroxyapatite at 1019, 558 , and $537 \mathrm{~cm}^{-1}$ [66-68], a $\left(\mathrm{CO}_{3}\right)^{2-}$ group as representative for the carbonated species or adsorbed carbon dioxide at 1417, 1338, and $871 \mathrm{~cm}^{-1}[69]$ and an $(\mathrm{OH})^{-}$group as an indication of the hydrated entities at 3213 and $1649 \mathrm{~cm}^{-1}$ [65] (Figure 8a). Detailing, the band centred at $871 \mathrm{~cm}^{-1}$ is a proof either of an A-type carbonated hydroxyapatite $\left(\left(\mathrm{CO}_{3}\right)^{2-}\right.$ group substituting $(\mathrm{OH})^{-}$group $)$or of a labile carbonate $\left(\left(\mathrm{CO}_{3}\right)^{2-}\right.$ absorped on the surface of apatite crystals or separated carbonate phase present with apatite crystals) $[69,70]$. The sharp band looming at $829 \mathrm{~cm}^{-1}$ could be related to additional vibrations of the bond between a metallic cation and $(\mathrm{OH})^{-}$group [68]. Moreover, the emergence of a maximum at $599 \mathrm{~cm}^{-1}$ is a specific fingerprint of hydroxyapatite [71]. The vibrational band typical of the Ti-O bond, which is located somewhere in the range $450-550 \mathrm{~cm}^{-1}$, is hidden by the more intense contributions of the $\left(\mathrm{PO}_{4}\right)^{3-}$ group $[16,72,73]$. The FTIR spectra registered on the samples subjected to heat treatments exhibit a well-defined individual band with a maximum around $720 \mathrm{~cm}^{-1}$ (Figure $8 b$ ); this is a mark of the vibrational characteristics of the $\left(\mathrm{P}_{2} \mathrm{O}_{7}\right)^{4-}$ group, which was formed by a condensation reaction between two $\left(\mathrm{HPO}_{4}\right)^{2-}$ groups at high temperatures [17,74].

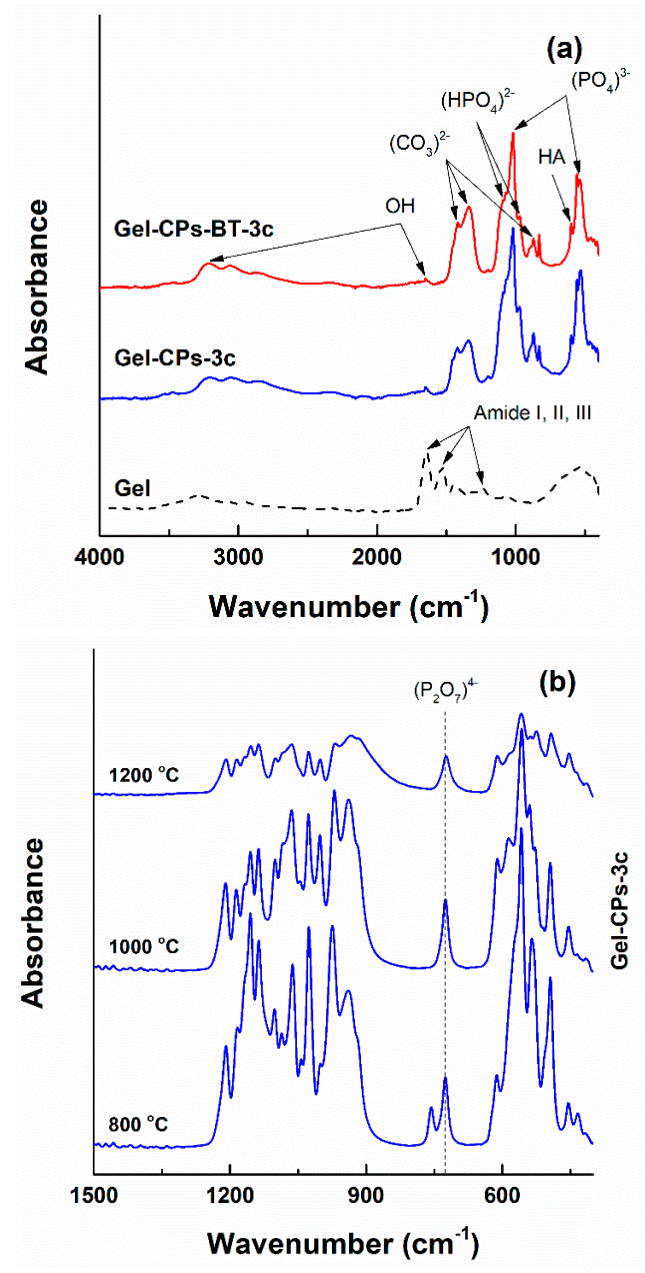

Figure 8. Cont. 


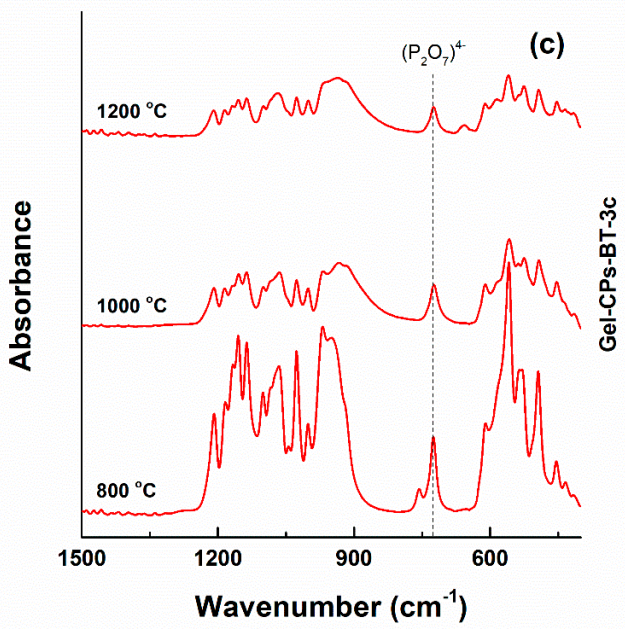

Figure 8. FTIR spectra of the obtained materials: (a) before the thermal treatments and $(\mathbf{b}, \mathbf{c})$ after the thermal treatments.

\section{Conclusions}

The present work describes the route for obtaining mineral scaffolds based on calcium phosphates and barium titanate, with clinical applicability in the field of hard tissue engineering. In order to ensure an adequate microstructure regarding pores size, shape, and arrangement, suitable for cell adhesion, proliferation, and differentiation, a polymeric template in the form of fibrous webs was used. Gelatine fibres achieved by electrospinning were loaded with calcium phosphates and then decorated with barium titanate nanoparticles, which were both performed under ultrasound irradiation. The resulting composites were transformed into mineral scaffolds by heat treatment in different experimental conditions, so that we proposed several types of implantable materials with varied morphologies. The mineralogical composition undergoes a transition due to the heat treatments from a mixture of brushite and hydroxyapatite to calcium pyrophosphate, while the microstructure mimics the fibres' layout for the lowest temperature and individualises as strengthened porous three-dimensional structures for the higher ones.

The future research will be dedicated to an extended biological evaluation of all developed materials, both from the perspective of the cell cultures response at different testing intervals, as well as the additional influence of a controlled external electric/magnetic field on the local amplification of the healing process.

Author Contributions: Conceptualisation, S.-I.J.; Funding acquisition, C.B.; Investigation, C.B., E.O. and A.-I.N.; Methodology, C.B., E.O., I.-C.S. and A.-I.N.; Resources, C.B. and I.-C.S.; Supervision, I.-C.S. and S.-I.J.; Validation, I.-C.S. and S.-I.J.; Writing—original draft, C.B. All authors have read and agreed to the published version of the manuscript.

Funding: This work was financially supported by the project Smart Scaffolds Built on Biocellulose 3D Architecture or Artificial Electrospun Templates for Hard Tissue Engineering (ScaBiES), PN-III-P1-1.1-TE-2016-0871 (contract number 66/2018), financed by the Executive Unit for Financing Higher Education, Research, Development and Innovation (UEFISCDI). The fabrication through electrospinning was possible due to the financial support of the European Regional Development Fund (6695072), through Competitiveness Operational Program 2014-2020, Priority axis 1, ID P_36_611, MySMIS code 107066, INOVABIOMED, Romania.

Acknowledgments: The authors thank A.D. Draghici for the schematic representation of the technological flow.

Conflicts of Interest: The authors declare no conflict of interest.

\section{References}

1. Lanza, R.; Langer, R.; Vacanti, J. Principles of Tissue Engineering; Academic Press: Cambridge, MA, USA, 2014.

2. Mohamed, K.R. Biocomposite materials. In Composites and Their Applications; Hu, N., Ed.; IntechOpen: London, UK, 2012. 
3. Voicu, G.; Jinga, S.I.; Drosu, B.G.; Busuioc, C. Improvement of silicate cement properties with bacterial cellulose powder addition for applications in dentistry. Carbohydr. Polym. 2017, 174, 160-170. [CrossRef] [PubMed]

4. Cunha, C.; Sprio, S.; Panseri, S.; Dapporto, M.; Marcacci, M.; Tampieri, A. High biocompatibility and improved osteogenic potential of novel Ca-P/titania composite scaffolds designed for regeneration of load-bearing segmental bone defects. J. Biomed. Mater. Res. A 2013, 101, 1612-1619. [CrossRef] [PubMed]

5. Jianmin, X.; Xiaocheng, W.; Endian, W.; Tian, L.; Jiang, C.; Chengtie, W. Bioinspired multifunctional biomaterials with hierarchical microstructure for wound dressing. Acta Biomater. 2019, 100, 270-279.

6. Fernandes, J.S.; Gentile, P.; Pires, R.A.; Reis, R.L.; Hatton, P.V. Multifunctional bioactive glass and glass-ceramic biomaterials with antibacterial properties for repair and regeneration of bone tissue. Acta Biomater. 2017, 59, 2-11. [CrossRef]

7. Antoniac, I.V. Handbook of Bioceramics and Biocomposites; Springer: New York, NY, USA, 2016.

8. Florencio-Silva, R.; da Silva Sasso, G.R.; Sasso-Cerri, E.; Simoes, M.J.; Cerri, P.S. Biology of bone tissue: Structure, function, and factors that influence bone cells. BioMed Res. Int. 2015, 2015, 421746. [CrossRef]

9. El-Fiqi, A.; Kim, J.H.; Kim, H.W. Novel bone-mimetic nanohydroxyapatite/collagen porous scaffolds biomimetically mineralized from surface silanized mesoporous nanobioglass/collagen hybrid scaffold: Physicochemical, mechanical and in vivo evaluations. Mater. Sci. Eng. C 2020, 110, 110660. [CrossRef]

10. Jinga, S.I.; Zamfirescu, A.I.; Voicu, G.; Enculescu, M.; Evanghelidis, A.; Busuioc, C. PCL-ZnO/TiO $/ 2 / \mathrm{HAp}^{2}$ electrospun composite fibres with applications in tissue engineering. Polymers 2019, 11, 1793. [CrossRef]

11. Cojocaru, F.D.; Balan, V.; Popa, M.I.; Lobiuc, A.; Antoniac, A.; Antoniac, I.V.; Verestiuc, L. Biopolymers-Calcium phosphates composites with inclusions of magnetic nanoparticles for bone tissue engineering. Int. J. Biol. Macromol. 2019, 125, 612-620. [CrossRef]

12. Jinga, S.I.; Constantinoiu, I.; Surdu, V.A.; Iordache, F.; Busuioc, C. Sol-gel-derived mineral scaffolds within $\mathrm{SiO}_{2}-\mathrm{P}_{2} \mathrm{O}_{5}-\mathrm{CaO}-\mathrm{MgO}-\mathrm{ZnO}-\mathrm{CaF}_{2}$ system. J. Sol-Gel Sci. Technol. 2019, 90, 411-421. [CrossRef]

13. Erasmus, E.P.; Sule, R.; Johnson, O.T.; Massera, J.; Sigalas, I. In vitro evaluation of porous borosilicate, borophosphate and phosphate bioactive glasses scaffolds fabricated using foaming agent for bone regeneration. Sci. Rep. 2018, 8, 3699. [CrossRef]

14. Cernencu, A.I.; Lungu, A.; Stancu, I.C.; Serafim, A.; Heggset, E.; Syverud, K.; Iovu, H. Bioinspired 3D printable pectin-nanocellulose ink formulations. Carbohydr. Polym. 2019, 220, 12-21. [CrossRef] [PubMed]

15. Terranova, L.; Dragusin, D.M.; Mallet, R.; Vasile, E.; Stancu, I.C.; Behets, C.; Chappard, D. Repair of calvarial bone defects in mice using electrospun polystyrene scaffolds combined with $\beta$-TCP or gold nanoparticles. Micron 2017, 93, 29-37. [CrossRef] [PubMed]

16. Draghici, A.D.; Busuioc, C.; Mocanu, A.; Nicoara, A.I.; Iordache, F.; Jinga, S.I. Composite scaffolds based on calcium phosphates and barium titanate obtained through bacterial cellulose templated synthesis. Mater. Sci. Eng. C 2020, 110, 110704. [CrossRef] [PubMed]

17. Busuioc, C.; Ghitulica, C.D.; Stoica, A.; Stroescu, M.; Voicu, G.; Ionita, V.; Averous, L.; Jinga, S.I. Calcium phosphates grown on bacterial cellulose template. Ceram. Int. 2018, 44, 9433-9441. [CrossRef]

18. Busuioc, C.; Stroescu, M.; Stoica-Guzun, A.; Voicu, G.; Jinga, S.I. Fabrication of 3D calcium phosphates based scaffolds using bacterial cellulose as template. Ceram. Int. 2016, 42, 15449-15458. [CrossRef]

19. Loh, Q.L.; Choong, C. Three-dimensional scaffolds for tissue engineering applications: Role of porosity and pore size. Tissue Eng. B 2013, 19, 485-502. [CrossRef]

20. Shuai, C.; Liu, G.; Yang, Y.; Yang, W.; He, C.; Wang, G.; Liu, Z.; Qi, F.; Peng, S. Functionalized BaTiO 3 enhances piezoelectric effect towards cell response of bone scaffold. Colloids Surf. B 2020, 185, 110587. [CrossRef]

21. Hendi, A.A.; Yakuphanoglu, F. Dielectric and ferroelectric properties of the graphene doped hydroxyapatite ceramics. J. Mol. Struct. 2020, 1207, 127734. [CrossRef]

22. Mitxelena-Iribarren, O.; Campisi, J.; Martinez de Apellaniz, I.; Lizarbe-Sancha, S.; Arana, S.; Zhukova, V.; Mujika, M.; Zhukov, A. Glass-coated ferromagnetic microwire-induced magnetic hyperthermia for in vitro cancer cell treatment. Mater. Sci. Eng. C 2020, 106, 110261. [CrossRef]

23. Aoki, K.; Haniu, H.; Kim, Y.A.; Saito, N. The use of electrospun organic and carbon nanofibers in bone regeneration. Nanomaterials 2020, 10, 562. [CrossRef]

24. Jin, Y.; Gao, Q.; Xie, C.; Li, G.; Du, J.; Fu, J.; He, Y. Fabrication of heterogeneous scaffolds using melt electrospinning writing: Design and optimization. Mater. Des. 2020, 185, 108274. [CrossRef] 
25. Wsoo, M.A.; Shahir, S.; Bohari, S.P.M.; Nayan, N.H.M.; Razak, S.I.A. A review on the properties of electrospun cellulose acetate and its application in drug delivery systems: A new perspective. Carbohydr. Res. 2020. [CrossRef] [PubMed]

26. Fahimirad, S.; Ajalloueian, F. Naturally-derived electrospun wound dressings for target delivery of bioactive agents. Int. J. Pharm. 2019, 566, 307-328. [CrossRef] [PubMed]

27. Esfahani, H.; Jose, R.; Ramakrishna, S. Electrospun ceramic nanofiber mats today: Synthesis, properties, and applications. Materials 2017, 10, 1238. [CrossRef]

28. George, A.; Sanjay, M.R.; Srisuk, R.; Parameswaranpillai, J.; Siengchin, S. A comprehensive review on chemical properties and applications of biopolymers and their composites. Int. J. Biol. Macromol. 2020, 154, 329-338. [CrossRef]

29. Niaounakis, M. Medical, dental, and pharmaceutical applications. In Biopolymers: Applications and Trends; Niaounakis, M., Ed.; William Andrew: Norwich, NY, USA, 2015.

30. Selaru, A.; Dragusin, D.M.; Olaret, E.; Serafim, A.; Steinmuller-Nethl, D.; Vasile, E.; Iovu, H.; Stancu, I.C.; Costache, M.; Dinescu, S. Fabrication and biocompatibility evaluation of nanodiamonds-gelatin electrospun materials designed for prospective tissue regeneration applications. Materials 2019, 12, 2933. [CrossRef]

31. Serafim, A.; Cecoltan, S.; Lungu, A.; Vasile, E.; Iovu, H.; Stancu, I.C. Electrospun fish gelatin fibrous scaffolds with improved bio-interactions due to carboxylated nanodiamond loading. RSC Adv. 2015, 5, 95467-95477. [CrossRef]

32. Chen, Y.; Lu, W.; Guo, Y.; Zhu, Y.; Song, Y. Electrospun gelatin fibers surface loaded ZnO particles as a potential biodegradable antibacterial wound dressing. Nanomaterials 2019, 9, 525. [CrossRef]

33. Ridi, F.; Meazzini, I.; Castroflorio, B.; Bonini, M.; Berti, D.; Baglioni, P. Functional calcium phosphate composites in nanomedicine. Adv. Colloid Interface Sci. 2017, 244, 281-295. [CrossRef]

34. Ben-Nissan, B. Advances in Calcium Phosphate Biomaterials; Springer: New York, NY, USA, 2014.

35. Sun, R.; Ahlen, M.; Tai, C.W.; Bajnoczi, E.G.; de Kleijne, F.; Ferraz, N.; Persson, I.; Stromme, M.; Cheung, O. Highly porous amorphous calcium phosphate for drug delivery and bio-medical applications. Nanomaterials 2020, 10, 20. [CrossRef]

36. Boccaccini, A.R.; Ma, P.X. Tissue Engineering Using Ceramics and Polymers; Woodhead Publishing: Sawston, UK, 2014.

37. Baptista, A.C.; Ferreira, I.; Borges, J.P. Electrospun fibers in composite materials for medical applications. J. Compos. Biodegrad. Polym. 2013, 1, 56-65. [CrossRef]

38. Chan, K.; Tsoi, J.K.H.; Wu, O.K.; Yon, M.J.Y.; Wong, R.W.K. Mechanical and biological evaluations of novel electrospun PLLA composite scaffolds doped with oxide ceramics. J. Mech. Behav. Biomed. Mater. 2019, 97, 229-237. [CrossRef] [PubMed]

39. Santos, D.; Correia, C.O.; Silva, D.M.; Gomes, P.S.; Fernandes, M.H.; Santos, J.D.; Sencadas, V. Incorporation of glass-reinforced hydroxyapatite microparticles into poly(lactic acid) electrospun fibre mats for biomedical applications. Mater. Sci. Eng. C 2017, 75, 1184-1190. [CrossRef]

40. Ahmed, M.K.; Ramadan, R.; El-dek, S.I.; Uskokovic, V. Complex relationship between alumina and selenium-doped carbonated hydroxyapatite as the ceramic additives to electrospun polycaprolactone scaffolds for tissue engineering applications. J. Alloys Compd. 2019, 801, 70-81. [CrossRef]

41. Liu, F.; Wang, X.; Chen, T.; Zhang, N.; Wei, Q.; Tian, J.; Wang, Y.; Ma, C.; Lu, Y. Hydroxyapatite/silver electrospun fibers for anti-infection and osteoinduction. J. Adv. Res. 2020, 21, 91-102. [CrossRef] [PubMed]

42. Kudryavtseva, V.; Stankevich, K.; Kibler, E.; Golovkin, A.; Mishanin, A.; Bolbasov, E.; Choynzonov, E.; Tverdokhlebov, S. The deposition of thin titanium-nitrogen coatings on the surface of PCL-based scaffolds for vascular tissue engineering. Appl. Phys. Lett. 2018, 112, 153705. [CrossRef]

43. Nandakumar, A.; Yang, L.; Habibovic, P.; van Blitterswijk, C. Calcium phosphate coated electrospun fiber matrices as scaffolds for bone tissue engineering. Langmuir 2010, 26, 7380-7387. [CrossRef]

44. Kraft, G.M.; Hire, C.C.; Santiago, A.; Adamson, D.H. Electrospun biomimetic catalytic polymer template for the sol-gel formation of multidimensional ceramic structures. Mater. Lett. 2019, 240, 242-245. [CrossRef]

45. Buscaglia, V.; Randall, C.A. Size and scaling effects in barium titanate. An overview. J. Eur. Ceram. Soc. 2020. [CrossRef]

46. Busuioc, C.; Voicu, G.; Jinga, S.I.; Mitran, V.; Cimpean, A. The influence of barium titanate on the biological properties of collagen-hydroxiapatite composite scaffolds. Mater. Lett. 2019, 253, 317-322. [CrossRef] 
47. Zanfir, A.V.; Voicu, G.; Busuioc, C.; Jinga, S.I.; Albu, M.G.; Iordache, F. New Coll-HA/BT composite materials for hard tissue engineering. Mater. Sci. Eng. C 2016, 62, 795-805. [CrossRef] [PubMed]

48. Zanfir, A.V.; Voicu, G.; Jinga, S.I.; Vasile, E.; Ionita, V. Low-temperature synthesis of $\mathrm{BaTiO}_{3}$ nanopowders. Ceram. Int. 2016, 42, 1672-1678. [CrossRef]

49. Fomekong, R.L.; You, S.; Enrichi, F.; Vomiero, A.; Saruhan, B. Impact of oxalate ligand in co-precipitation route on morphological properties and phase constitution of undoped and $\mathrm{Rh}$-doped $\mathrm{BaTiO}_{3}$ nanoparticles. Nanomaterials 2019, 9, 1697. [CrossRef] [PubMed]

50. Manea, L.R.; Popa, A.; Bertea, A.P. Medical applications of functional electrospun nanofibers-A review. Key Eng. Mater. 2017, 752, 132-138. [CrossRef]

51. Kim, Y.J.; Lee, S.Y.; Roh, Y.; Lee, J.; Kim, J.; Lee, Y.; Bang, J.; Lee, Y.J. Optimizing calcium phosphates by the control of $\mathrm{pH}$ and temperature via wet precipitation. J. Nanosci. Nanotechnol. 2015, 15, 10008-10016. [CrossRef]

52. Chuaynukul, K.; Prodpran, T.; Benjakul, S. Preparation, thermal properties and characteristics of gelatin molding compound resin. Res. J. Chem. Environ. Sci. 2014, 2,1-9.

53. Singh, M.; Yadav, B.C.; Ranjan, A.; Kaur, M.; Gupta, S.K. Synthesis and characterization of perovskite barium titanate thin film and its application in LPG sensor. Sens. Actuators B 2017, 241, 1170-1178. [CrossRef]

54. Hayashi, H.; Nakamura, T.; Ebina, T. In-situ Raman spectroscopy of $\mathrm{BaTiO}_{3}$ particles for tetragonal-cubic transformation. J. Phys. Chem. Solids 2013, 74, 957-962. [CrossRef]

55. Verma, K.C.; Sharma, A.; Goyal, N.; Kotnala, R.K. Ferromagnetism in multiferroic $\mathrm{BaTiO}_{3}$, spinel $\mathrm{MFe}_{2} \mathrm{O}_{4}$ $(\mathrm{M}=\mathrm{Mn}, \mathrm{Co}, \mathrm{Ni}, \mathrm{Zn})$ ferrite and DMS ZnO nanostructures. In Electromagnetic Materials and Devices; Han, M.G., Ed.; IntechOpen: London, UK, 2020.

56. Bahoosh, S.G.; Trimper, S.; Wesselinowa, J.M. Origin of ferromagnetism in $\mathrm{BaTiO}_{3}$ nanoparticles. Phys. Status Solidi 2011, 5, 382-384. [CrossRef]

57. Kim, D.W.; An, J.S.; Cho, I.S. Effects of Mg and Sr co-addition on the densification and biocompatible properties of calcium pyrophosphate. Ceram. Int. 2018, 44, 9689-9695. [CrossRef]

58. El-Kady, A.M.; Mohamed, K.R.; El-Bassyouni, G.T. Fabrication, characterization and bioactivity evaluation of calcium pyrophosphate/polymeric biocomposites. Ceram. Int. 2009, 35, 2933-2942. [CrossRef]

59. He, Y.; Zhang, Y.; Meng, Z.; Jiang, Y.; Zhou, R. Microstructure evolution, mechanical properties and enhanced bioactivity of Ti-Nb-Zr based biocomposite by bioactive calcium pyrophosphate. J. Alloys Compd. 2017, 720, 567-581. [CrossRef]

60. Filippov, Y.Y.; Orlov, E.D.; Klimashina, E.S.; Evdokimov, P.V.; Safronova, T.V.; Putlayev, V.I.; Rau, J.V. Colloidal forming of macroporous calcium pyrophosphate bioceramics in 3D-printed molds. Bioact. Mater. 2020, 5 , 309-317. [CrossRef] [PubMed]

61. Ahmed, M.; Ramos, T.; Wieringa, P.; van Blitterswijk, C.; de Boer, J.; Moroni, L. Geometric constraints of endothelial cell migration on electrospun fibres. Sci. Rep. 2018, 8, 6386. [CrossRef] [PubMed]

62. Hasmad, H.; Yusof, M.R.; Razi, Z.R.M.; Idrus, R.B.H.; Chowdhury, S.R. Human amniotic membrane with aligned electrospun fiber as scaffold for aligned tissue regeneration. Tissue Eng. C 2018, 24, 368-378. [CrossRef]

63. Lyu, S.; Huang, C.; Yang, H.; Zhang, X. Electrospun fibers as a scaffolding platform for bone tissue repair. J. Orthop. Res. 2013, 31, 1382-1389. [CrossRef]

64. Das, M.P.; Suguna, P.R.; Prasad, K.; Vijaylakshmi, J.V.; Renuka, M. Extraction and characterization of gelatin: A functional biopolymer. Int. J. Pharm. Pharm. Sci. 2017, 9, 239-242. [CrossRef]

65. Idowu, B.; Cama, G.; Deb, S.; Di Silvio, L. In vitro osteoinductive potential of porous monetite for bone tissue engineering. J. Tissue Eng. 2014, 5, 1-14. [CrossRef]

66. Lee, H.B.; Hsu, H.C.; Wu, S.C.; Hsu, S.K.; Wang, P.H.; Ho, W.F. Microstructure and characteristics of calcium phosphate layers on bioactive oxide surfaces of air-sintered titanium foams after immersion in simulated body fluid. Materials 2016, 9, 956. [CrossRef]

67. Koroleva, L.F.; Larionov, L.P.; Gorbunova, N.P. Biomaterial based on doped calcium carbonate-phosphate for active osteogenesis. J. Biomater. Nanobiotechnol. 2012, 3, 226-237. [CrossRef]

68. Jastrzebski, W.; Sitarz, M.; Rokita, M.; Bulat, K. Infrared spectroscopy of different phosphates structures. Spectrochim. Acta A 2011, 79, 722-727. [CrossRef] [PubMed] 
69. Prekajski, M.; Mirkovic, M.; Todorovic, B.; Matkovic, A.; Marinovic-Cincovic, M.; Lukovic, J.; Matovic, B. Ouzo effect-New simple nanoemulsion method for synthesis of strontium hydroxyapatite nanospheres. J. Eur. Ceram. Soc. 2016, 36, 1293-1298. [CrossRef]

70. Brzezinska-Miecznik, J.; Jelen, P.; Haberko, K.; Mozgawa, W.; Sitarz, M. The effect of NaOH and KOH treatment on the behavior of $\mathrm{CO}_{3}{ }^{2-}$ and $\mathrm{OH}^{-}$groups in natural origin hydroxyapatite. Ceram. Int. 2017, 43, 12540-12545. [CrossRef]

71. Brundavanam, S.; Poinern, G.E.J.; Fawcett, D. Growth of flower-like brushite structures on magnesium substrates and their subsequent low temperature transformation to hydroxyapatite. Am. J. Biomed. Eng. 2014, 4, 79-87.

72. Ashiri, R. Detailed FT-IR spectroscopy characterization and thermal analysis of synthesis of barium titanate nanoscale particles through a newly developed process. Vib. Spectrosc. 2013, 66, 24-29. [CrossRef]

73. Chinchamalatpure, V.R.; Ghosh, S.A.; Chaudhari, G.N. Synthesis and electrical characterization of $\mathrm{BaTiO}_{3}$ thin films on Si(100). Mater. Sci. Appl. 2010, 1, 187-190. [CrossRef]

74. Berzina-Cimdina, L.; Borodajenko, N. Research of calcium phosphates using Fourier Transform Infrared Spectroscopy. In Infrared Spectroscopy_Materials Science, Engineering and Technology; Theophanides, T., Ed.; IntechOpen: London, UK, 2012.

(C) 2020 by the authors. Licensee MDPI, Basel, Switzerland. This article is an open access article distributed under the terms and conditions of the Creative Commons Attribution (CC BY) license (http://creativecommons.org/licenses/by/4.0/). 